\title{
A DELICATE BALANCE: WHITMAN'S STANZAIC POEMS
}

\author{
JOHN E. SCHWIEBERT
}

ONLY SLIGHTLY LESS FAMOUS than Whitman's democratic philosophy is his radical rejection of traditional prosody. In an 1880 interview he remarked,

. . I I have rejected the rhymed and blank verse. I have a particular abhorrence of blank verse, but I cling to rhythm; not the outward, regularly measured, short foot, long foot-short foot, long foot-like the walking of a lame man, that I care nothing for. The waves of the sea do not break on the beach every so many minutes; the wind does not go jerking through the pine trees, but nevertheless in the roll of the waves and in the soughing of the wind in the tree there is a beautiful rhythm. How monotonous it would become, how tired the ear would get of it if it were regular! ${ }^{1}$

This is not the only case of an inconsistency between Whitman's theoretical pronouncements about poetry and his actual poetic practice. Critics have long noted that many of Whitman's poems, particularly those written during the Civil War and after, approximate traditional accentual-syllabic meters. Yet there is also an element of truth in Whitman's statement about rhythm. Even when he wrote "traditionally," Whitman at his best was capable of using stanzas and meters subtly and skillfully, without being merely "monotonous."

This essay examines Whitman's use of stanzaic forms and of accentual-syllabic meters in several poems written during and after the Civil War, with the aim of showing how-even in his more traditional poems - he often avoided the "short foot, long foot" rhythm "like the walking of a lame man" by using poetic structures that are novel and yet suggestive of traditional forms and rhythms.

Scholars have treated Whitman's traditional techniques peripherally and with some ambivalence. ${ }^{2}$ Most, moreover, have focused on the poems in which meter and/or rhyme and stanza are most obtrusive, such as "O Captain! My Captain!" and "Pioneers! O Pioneers!" Consequently, they have neglected some of Whitman's better traditional poems, in which stanza and meter figure more subtly yet nonetheless instrumentally in the poem. After looking briefly at some of the more obviously traditional poems, it is on these poems that I wish to focus.

Whitman's best stanzas are invented stanzas; his best meters, in the traditional poems, approximate accentual-syllabic meters without following them rigidly. In these poems stanza and meter are expressive 
without being merely distracting because they work subtly with a range of other familiar Whitmanesque techniques, from diction and syntax to symbolism. Considering Whitman's organicism, it is natural that meter and stanza in his better efforts should not seem devices fabricated or "artificially" imposed on poetic materials but consistent with and subtly reinforcing those materials - the meter being as much a part of the "natural" evolution of the poem as any feature of a poem (intrinsically a work of "artifice") can be.

Setting aside his juvenile poems, which - with their various uses of ballad and ode stanzas, iambic tetrameter, and blank verse-are chiefly interesting as artifacts of Whitman's poetic development, ${ }^{3}$ Whitman's most conventional efforts at meter and stanza are exemplified in three poems - "O Captain! My Captain!" (1865-1866), "The Singer in the Prison" (1869), and "Ethiopia Saluting the Colors" (1871).

"O Captain! My Captain!" (LG, p. 337) has three eight-line stanzas with a refrain, which is slightly varied from stanza to stanza. ${ }^{4}$ The meter is iambic and expressively ballad-like; most of the long lines can be relineated to create ballad stanzas. For instance,

The ship has weathered every rack,

The prize we sought is won,

The port is near, the bells I hear,

The people all exulting . . .

With its elegiac theme, the poem obviously suffers from comparison with its infinitely more complex neighbor in Leaves, "When Lilacs Last in the Dooryard Bloom'd." In fact (and perhaps partly because of its massive popularity in Whitman's own time), "Captain" has often been derided as an example of the esthetic depths to which Whitman could sink when he tried to write metrically like other poets. But within its modest scope, so unlike the polyphonic music of "Lilacs," "Captain" has some notable technical effects. For instance, the refrain is expressively varied from stanza to stanza to intensify the pathos of the speaker's realization of his captain's death. Still, the expressive use of refrain and stanza is more strained-and less densely psychological-than in another poem of the same year, "Old War-Dreams," which will be discussed in a moment.

In "The Singer in the Prison" ( $L G$, p. 376) a woman brings tears to the "crafty, brutal, seam'd and beauteous faces" of convicts by singing "a quaint old hymn" to them in the prison church. Her "hymn," the plaint of the soul against the body ("It was not I that sinn'd the sin, / The ruthless body dragg'd me in"), concludes with the comforting words: "Dear prison'd soul bear up a space, / For soon or late the certain grace ... ."From a formal standpoint, the poem is unusual within Whitman's work, juxtaposing sharply differentiated free and 
traditional forms. While other lines in the poem's three sections are in "free" form, the hymn uses conventional hymn stanza and meter $(a a(4) b b(4))$.

A soul $\mid$ confined $\mid$ by bars $\mid$ and bands, Cries, help! | O help! | and wrings | her hands, Blinded | her eyes, | bleeding | her breast, Nor par|don finds, | nor balm $\mid$ of rest.

With its dramatic implausibility (why would this hymn make hardened convicts cry?), obtrusively sentimental moral, and denigration of the human body, "The Singer" seems as atypical thematically of Whitman as it is stylistically. Though somewhat redeemed by the surrounding free verse text, the "hymn" portion of the poem seems to substantiate Richard Chase's charge that "Whitman cannot approach too closely to conventional meter without becoming . . . not so much conventional as merely mechanical." $" 5$

The third of the very traditional poems, "Ethiopia Saluting the Colors" ( $L G$, pp. 318-319), is a 15-line work in iambic meter and divided into five stanzas of three lines each. For instance,

Who are | you, dusk|y woman, | so an|cient hard|ly human,

With your wool|ly-white | and tur|ban'd head, | and bare | bony feet?

Why ris|ing by $\mid$ the road|side here, $\mid$ do you $\mid$ the col|ors greet?

The first line of each stanza has internal rhyme (e.g., "woman" / "human") and the second and third lines are end-rhymed, so that each stanza has the approximate pattern of $(a) a 6 b b 7 .^{6}$ Like "Captain," the poem is suggestively ballad-like: many of the long seven-foot lines have a syntactic pause after the fourth foot that invites relineation into two shorter lines, such as: "With your woolly-white and turban'd head, I And bare bony feet? / Why rising by the roadside here, / Do you the colors greet?" The result suggests a loose variation of the traditional $a(4) b(3) c(4) b(3)$ ballad stanza.

If this generally unremarkable poem has an expressive element, it may be the peculiar rhythm, diction, and syntax in the one stanza (the third) spoken by "Ethiopia," the ancient slave woman who "salutes" the passing "colors" of General Sherman's army.

Me master years a hundred since from my parents sunder'd, A little child, they caught me as the savage beast is caught, Then hither me across the sea the cruel slaver brought.

One critic suggests that the ungrammatical syntax, crude diction, and halting rhythm (note the awkward stress forced on the preposition "from" by the meter) help to characterize the psychological simplicity of 
the speaker ${ }^{7}$-though it seems just as probable that the stanza's technical infelicities are self-conscious blunders by a poet who was temperamentally unfit to write ballads.

Poems like "Ethiopia" seem to represent a regression by Whitman into the strained mannerisms of his juvenilia. ${ }^{8}$ Here, after forging a new and liberating style for himself in "Song of Myself," Whitman inexplicably revives the rigidly conventional forms he had abandoned in the 1840 s, forms that fit him like an esthetic - not to mention emotional and intellectual-straitjacket. Fortunately, however, Whitman's affair with tradition does not end with regression. James Wright astutely observes that Whitman, at his best, learned from tradition to surpass it. ${ }^{9}$ Three poems that demonstrate this point are "Beat! Beat! Drums!" (1861), "Darest Thou Now O Soul" (1868), and "Old War-Dreams" (18651866). While none of these works has entered the pantheon of Whitman's greatest poems, they nonetheless show how the poet could exploit stanza and meter in natural, purposeful, and evocative ways.

"Beat! Beat! Drums!" ( $L G$, pp. 283-284) is one of a handful of "recruiting" poems Whitman wrote at the outset of the Civil War. ${ }^{10}$ The poem places us in a disturbing world. Instead of inveighing against war and bloodshed, as one might expect of Whitman the "motherpoet," the poem explicitly and loudly invokes war. But beneath its surface bellicosity, the poem suggests some genuine (conscious or unconscious) ambivalence about the war. Structurally, it seems to have a double identity. Strictly speaking it is in free verse: there is no fixed and predictable number of syllables or stresses per line, nor is there any fixed pattern in the number of stresses per number of syllables. Yet the poem has several features which link it with traditional verse. It is broken into stanzas of exactly seven lines each, with each stanza having a refrain-like pattern of repetition in the first and last lines:

Beat! beat! drums!-blow! bugles! blow!

. . . So fierce you whirr and pound you drums - so shrill you bugles blow. $(11.1,7)$

Beat! beat! drums!-blow! bugles! blow!

. . . Then rattle quicker, heavier drums-you bugles wilder blow. (11. 8, 14)

Beat! beat! drums!-blow! bugles! blow!

. . . So strong you thump O terrible drums - so loud you bugles blow. (11. 15, 21)

Moreover, though the meter is not strictly iambic, the final line of each stanza is a perfect seven-foot iambic.

These traditional verse elements in the poem do not seem accidental. On the one hand, they seem to evoke the "drums" and "bugles," whose insistent, march-like rhythm is reasserted with each refrain-like repetition - by the heavy stress pattern of the first, eighth, and fifteenth lines and by the perfect iambs of the seventh, fourteenth, and twenty- 
first. On a subtler level, traditional elements also accentuate the poem's many departures, particularly its rhythmic departures, from traditional pattern.

The latter point becomes clear if we compare Whitman's poem with a poem composed a few years earlier by Tennyson- "Tears, Idle Tears." While "The Splendor Falls" and its "Blow, bugle, blow" refrain suggest the most obvious Tennysonian analogue with "Beat!," "Tears" invites the more striking metrical comparison. Like "Beat!," "Tears" consists of stanzas of uniform length (five lines) and each stanza concludes with a line that is nearly the same from stanza to stanza:

And thinking of the days that are no more. (1. 5)

So sad, so fresh, the days that are no more. (1. 10)

So sad, so strange, the days that are no more. (1. 15)

But Tennyson's poem is in iambic pentameter, and after a few lines the pulse of his regular, decasyllabic lines creates a pattern of rhythmic inevitability; one begins each line feeling exactly when it will end. While there is surely metrical variety - not to mention intricate soundplaywithin lines, the mold of one stanza, with its fifty syllables, is the same as the others. Whitman's poem, on the other hand, suggests diverse meters, ranging from what could be scanned as loose iambic:

Into | the sol|emn church, | and scat|ter the con|gregation, (1. 3)

to dactyllic:

Into the $\mid$ school where the $\mid$ scholar is $\mid$ studying; (1. 4)

to iambic-anapestic:

Nor the peace|ful farm|er an|y peace, | ploughing | his field | or gath|ering his grain. . . . (1. 6)

Moreover, Whitman's lines are not of uniform length, but vary dramatically from the seven syllables of the first, eighth, and fifteenth lines to the twenty-one syllables of line eleven:

No bargainers' bargains by day-no brokers or speculators-would they continue?

Such flexibility in rhythm and line length in turn creates flexible and varied stanzas. One does not begin a new line, as in the Tennyson poem, with the sense that it will be like the line before, but with an alertness to how the new line may be different. Ultimately, the poem's blending of traditional and free verse elements suggests a stylistic parallel to a 
central theme in the poem. The poem is about a world thrown off its center, in which the sounds of war drown out the activities of peace. The destabilizing power of war clashes with the stability of peace, and this conflict resonates in the tension between free (i.e., destabilizing) and traditional (stable) verse elements.

The ominous rhythmic effects of the poem are reinforced by syntax. In all versions of the poem, including that of the 1891-1892 Leaves, each stanza is printed as a single sentence. This seems true even of the second stanza, with its five question marks:

Are beds prepared for sleepers at night in the houses? (1. 9)

Would the talkers be talking? would the singer attempt to sing? (1. 12), etc.

Except where the first word after a question mark is printed as the start of a new line (and would therefore be capitalized anyway), the first letter after each question mark is always printed in lower case, suggesting that Whitman considered the question marks as mid-sentence rather than end-sentence punctuations. Yet within these stanza-long sentences are numerous syntactic units which might be printed as sentences. While the interrogatives in the second stanza are the most obvious examples, this is also true of numerous other lines and half-lines, such as the second half of line five ("- no happiness must he have now with his bride"). Whitman's peculiar punctuation serves an important stylistic purpose. By following a "sentence" such as the one quoted with a comma rather than a period, he seemed to deprive it of its syntactic integrity. Instead of standing alone, it becomes merely one phrase among many, to be quickly passed over in reading. As a syntactic unit, it is thrust asidemuch as "the bridegroom" it describes is thrust aside by the encroachments of war.

The poem's long seven-line sentences are sustained by intricate and sonorous phrasing. Parallelism and anaphora, in particular, give the poem a ring of prophetic authority reminiscent of Biblical phrasing. So also do the poem's many masterful shifts in voice and mood, from imperative ("Beat! beat! drums!-blow! bugles! blow!"; "Burst like a ruthless force . . .") to interrogative ("Are beds prepared for sleepers at night in the houses? . . . / . . . would they continue?") and back to imperative ("Make no parley ...."). Within the larger syntactic structures of the poem, which are primarily governed by the imperative or interrogative moods, are embedded indicative phrases: e.g., "-no happiness must he have now with his bride" (1. 5); ". . . no sleepers must sleep in those beds" (1. 10). These phrases, by complicating the syntax, delay sentence-endings and thereby heighten suspense.

Whitman also varies syntax by means of dramatic variations in phrase lengths, which strengthen the poem's rhetorical impact. Perhaps 
the most impressive example of this is in the third stanza, which builds, line by line, from the relatively short imperative phrases of line sixteen ("Make no parley-stop for no expostulation") to the hair-raising penultimate line of the poem: "Make even the trestles to shake the dead where they lie awaiting the hearses. . . ."

"Beat! Beat! Drums!" is clearly a disturbing poem; it is about the disturbance and disruption of peace and stability, and much of its effectiveness results from the way syntax is repeatedly disrupted and disturbed. Parallelism and anaphora give the poem a certain surface smoothness in which one line moves deftly into another:

Through the windows-through doors . . .

Into the solemn church . . .

Into the school . . . (11. 2-4)

Leave not the bridegroom quiet-no happiness must he have now with his bride,

Nor the peaceful farmer any peace, ploughing his field or gathering his

grain . . (11. 5-6)

Would the talkers be talking? would the singer attempt to sing?

Would the lawyer rise . . . ? (11. 12-13)

But sewn among these patterns of syntactic parallelism are violations of pattern which become the more striking for the very presence of the pattern they violate. For instance, the first two stanzas both begin with the same line. Both continue with a line which contains two parallel phrases: "Through the windows-through doors" (1. 2); "Over the traffic of cities-over the rumble of wheels" (1. 8). Thus far the two stanzas are syntactically parallel. But while stanza one, line three continues to accumulate prepositional phrases, stanza two, line three departs decisively from pattern by shifting suddenly to the interrogative mood: "Are beds prepared for sleepers at night in the houses?" The opening of stanza three departs even more clearly from the patterns set in the first two stanzas; there, no prepositional phrases appear, and the syntax moves immediately from the imperatives of the opening line to a succession of other imperatives: "Make no parley-stop for no expostulation," etc. Again, these shifts and changes in syntax seem the more striking for occurring within a context of so much parallelism and pattern.

In "Beat! Beat! Drums!" traditional and nontraditional elements fuse to evoke a mood of excitement, suspense, and imminent danger. "Darest Thou Now O Soul" ( $L G$, p. 441$)$, a slightly later poem, exploits traditional features to similar effect, though here the excitement-consistent with the spirit of the aging Whitman-is mystical rather than horrific. The poem treats a subject dear to the death-obsessed poet of the post-war years, the theme of the soul's voyage into the unknown. This theme, and the pattern of movement evoked by the poem (from 
known to unknown), is imaginatively captured and intensified by the poem's particular stanzaic form. Each stanza begins with a short line followed by two progressively longer lines. In the opening stanza the lines have six, ten, and fifteen syllables, respectively, and in the second stanza five, ten, and fourteen syllables.

Darest thou now O soul,

Walk out with me toward the unknown region,

Where neither ground is for the feet nor any path to follow?

No map there, nor guide,

Nor voice sounding, nor touch of human hand,

Nor face with blooming flesh, nor lips, nor eyes, are in that land.

The stanza shape seems intuitively appropriate to the theme. The poet extends a "dare." By definition, "to dare" is to invite a movement by the one dared from the known to the unknown, from the familiar to a realm of uncertain outcome or consequences. This thematic notion is suggestively paralleled, structurally, in lines that do not stabilize at a fixed length or in a predictable pattern of alternating lengths, but rather simply get longer. In this respect, they somewhat resemble Hardy's stanzas in "The Convergence of the Twain," which also deals with the approach of an imminent unknown; though Hardy's "unknown" (the ruin of the Titanic) is ironically known in advance, his stanzas are end-rhymed, and the lines within a stanza are of only two different lengths $(a a 3 a 6)$ rather than three.

At the same time other, stabilizing patterns are at work in the line and stanza. Many lines have an iambic rhythm which is suggestive of regularity and order; for instance:

Walk out | with me | toward | the un|known region. . . . (1. 2)

Nor face | with bloom|ing flesh, | nor lips, | nor eyes, | are in | that land. (1. 6) All but $\mid$ the ties | eter|nal, Time | and Space. . . . (1. 11)

In addition, each stanza ends with a full syntactic stop, which emphasizes a proximate durational equality among stanzas. Such terminal punctuation lends weight and grandeur to the pause and silence between stanzas. Finally, while lines within each stanza are of irregular lengths, the stanzas themselves all follow a uniform pattern of short line, longer line, longest line. By the time one reaches the second stanza this pattern has become predictable and one is struck, as Bradley and Blodgett point out, by the stanzas' "impressive . . . regularity" ( $L G$, p. $441 \mathrm{n}$ ).

Thus patterns in line and stanza suggest a significant tension between two possibilities related to the central "dare" of the poem: on the one hand, uncertainty or danger, as evoked by the irregular lengthening 
lines within stanzas; on the other hand, confidence or self-assurance, as evoked by rhythm, punctuation, and the uniformity of line patterning across stanzas.

Other features of the poem, such as rhetorical stance and diction, reinforce these contrary possibilities. The poet addresses his soul with a calmness and assurance that the rhetorical situation underscores. The poet is in the role of initiator. Not at all a passive victim being "pushed" into a frightening voyage against his will, he is eager to embark; he calmly advises his soul on the nature of the journey it and he are about to undertake. He seems to have thought his subject out thoroughly and patiently in advance:

$\mathrm{I}$ know it not $\mathrm{O}$ soul,

Nor dost thou, all is a blank before us,

All waits undream'd of in that region, that inaccessible land.

Till when the ties loosen,

All but the ties eternal, Time and Space,

Nor darkness, gravitation, sense, nor any bounds bounding us.

In loving detail he prognosticates about the imminent journey: The "ties" will "loosen," and

Then we burst forth, we float,

In Time and Space $\mathrm{O}$ soul, prepared for them,

Equal, equipt at last ( $\mathrm{O}$ joy! $\mathrm{O}$ fruit of all!) them to fulfill $\mathrm{O}$ soul.

At the same time, and countering this confidence so subtly as almost to go unnoticed, the poem is riddled with negative word constructions which promote a sense of tentativeness and transcendent mystery: "unknown," "neither," "nor" in stanza one; "No" and "nor" (repeated five times) in stanza two; "not," "nor," "undream'd," "inaccessible," in the third stanza; etc. The poet speaks of his and the soul's destination only in terms of what it is not. His name for it is not "heaven" or "the beyond" or some other such positive and specific epithet but, more cryptically, "the unknown region." The "region," moreover, is not a place with positive, identifiable features but one "Where neither ground is for the feet nor any path to follow" (italics mine). Nor can the speaker describe it sensually:

No map there, nor guide,

Nor voice sounding, nor touch of human hand,

Nor face with blooming flesh, nor lips, nor eyes, are in that land.

The pattern of self-assurance and mystery continues until the last stanza. Characteristically for Whitman, assurance has the final say: there are no negative word constructions in the last stanza. But the atmo- 
sphere of mystery and daring permeates the poem. The complex emotions the speaker feels as he contemplates his "walk out" into the unknown are held in delicate and intense equilibrium.

"Old War-Dreams" ( $L G$, p. 484), another of Whitman's quasitraditional poems, shares with "Darest Thou" a mood of subtle introspection. Moreover, like "Darest Thou," it addresses one of the aging Whitman's obsessive concerns: in this case, his war-haunted memory. Scholars have analyzed and psychoanalyzed Whitman's experience as nurse in the Civil War hospitals, an experience Whitman himself regarded as "pivotal" to his own life and to Leaves of Grass. "Without those three or four years and the experiences they gave," he wrote in 1888 , "Leaves of Grass' would not now be existing." 11 Recently, M. Wynn Thomas has examined Whitman's ambivalent feelings about the place and function of the war in memory, both Whitman's own and the nation's. Thomas shows that Whitman wished both to remember and to forget; to keep alight the holy fire of wartime struggle and idealism, on the one hand-a flame that he felt had catalyzed the democratic potential of the nation as had no event since the American Revolution-and to let the past be past, on the other. ${ }^{12}$

Various poems, such as "The Artilleryman's Vision" and "The Wound-Dresser" (both poems of 1865), articulate this obsessive concern of Whitman's. But "The Wound-Dresser" is sixty-five lines long, and what is especially remarkable about the twelve-line "Old War-Dreams" is that it treats so complicated a theme so compactly and well. Given the magnitude of its subject, one might expect the texture of the poem to be dense; and it is. Moreover, the stanza form, along with other features, contributes to the poem's density and expressiveness.

The title provides a first clue to the poem's content. The adjective "old," placed focally at the start of the title and the poem, is not incidental but central. The poem, we project, will be about "old" or recurring dreams, as experienced by a speaker likely to reflect on such things, such as an aging veteran. Even as we read the title, a glance at the poem's typographical shape on the page shows order; without getting so far as counting lines or syllables or stresses, or determining patterns of similarity across line groupings, we recognize instantly that the poem falls into three stanzas. But if this leads us to expect "orderliness" from what we are about to read, we are simultaneously confronted with a problem: this anticipation of a tidily arranged pattern of lines to come is undercut by the sense of psychological disturbance hinted at in the title. Which is it to be-unrest and disturbed dreams? or well-ordered stability? Our perplexity deepens as, venturing beyond the title into the poem proper, we find ourselves entering a difficult syntactic maze. In naming his poem, it seems, the speaker titled it accurately; for the order and manner in which perceptions and images are related to 
us resembles nothing so much as the disjunctive and disordered revelations of dreams, which await translation into pragmatic, rationally comprehensible discourse.

In describing his dreams the speaker's need seems only partially met: he has gotten the facts of his vision verbalized. The greater task is somehow to construct from the fragmented messages of his unconscious a meaning for his waking, conscious life; to clear the paths between his unconscious and conscious mind. It is in the ongoing process of deciphering and arranging the raw materials of the unconscious that the speaker's real work occurs.

All this affects our reading of the poem. Whitman demands nothing so much as our empathetic participation in his poem; his experience must be our experience. As he wrestles with inscrutabilities, so must we wrestle; as he obsessively revisits and interrogates his dreams, so must we revisit and interrogate them-and intensely so, experiencing the dreams as our own. Thus our process of reading in "Old War-Dreams" suggestively parallels the intellectual and emotional effort of the speaker. Picking our indeterminate way through the poem, we act out the speaker's own process of reconstruction, of sifting through his/our dreams and reordering them into pragmatically coherent patterns. The speaker, as far as we know, has not yet identified any particular significance to his dreams. Thus the process of reordering, rather than any static "meaning," becomes an integral part of what the poem is about.

This process of reordering, and the need for it, is already obvious in the previously mentioned disjunction between the poem's disturbing title and its orderly stanza shape. It intensifies as we begin the poem proper. In the opening stanza we are unsure at first of the syntactic relationship between one phrase and the next. The "of many a face of anguish" of line one may seem at first to modify "sleep" (i.e., the sleep of "many" anguished faces); but this reading becomes problematic in lines two and three when three consecutive constructions that are apparently parallel to "of many a face" do not seem at all to refer back syntactically to "sleep." Not till the introduction of the main subject and verb in line four do we realize that all four "of" phrases are objects of the verb, "dream." Thus only gradually do the syntactic relations among the various phrases in the stanza become clear.

The syntax is also striking in other ways. It is not the subject-verbobject order of straightforward syntax, which would render "I dream of $\mathrm{X}$, of $\mathrm{Y}$, and of Z." Instead, the noun objects of the verb are presented first-"many a face," "the look," "the dead"-and only after much delay do the main subject and verb appear in "I dream." The pattern of delay, and of syntactic embedding and inversion that requires us to read to the end of a section to determine the sentence pattern, resembles the opening section of "The Wound-Dresser," where even speakers are 
difficult to identify amid the smoke and haze of contorted syntax ( $L G$, pp. 308-309). Logical, pragmatic word order is superseded by immediacy, by the intuitive order in which things seem rendered up by the unconscious.

Having read stanza one, we can predict that the "Of" that opens stanza two will introduce other objects of the speaker's dreams. But this stanza, too, is not without its maze-like qualities-though here the source of the mental and emotional effort we must expend in reading is not so much syntactic as lexical. The noun objects in the first stanza were all drawn from the lexical category of warlike scenes and experiences: "many a face of anguish," "the look . . . of the mortally wounded," "the dead." Now, following the opening "of" of the second stanza, where one might anticipate a continuation of gory, battlefield imagery, come images and words that seem unaccountably remote from war's hell scenes: "scenes of Nature," "fields and mountains," "skies so beauteous after a storm," "the moon." And in line seven, where the moon is described as - of all things - "Shining sweetly," the context seems even more radically distant from the one evoked at the outset of the poem. Whitman was fond of comparing his poetry to opera, and his bold departures in this stanza from the imagery of the first somewhat resemble the musical modulations of a Mozart sestet, which stray from the dominant key in dazzling and daring ways without once losing the thread of continuity; so, here, Whitman taxes our expectations without disappointing them.

As syntactic puzzlement experienced in the first stanza was quickly generated and as quickly resolved in that stanza, so a brief but intense puzzlement over thematic direction in stanza two is resolved in the latter half of line seven, when the pastoral interlude abruptly ends with "where we dig the trenches and gather the heaps"-a phrase that instantaneously returns us to the nightmare imagery of stanza one. In a poem striking for its plain diction, "heaps" seems the precisely authentic word for the objects described. To the persona, faithfully reporting his dreams, the dead soldiers are not "the dead," or "the corpses," or-still more romantically - "the fallen," but "the heaps." The noun does not evoke any animate qualities of the subjects; only a leisurely observer could detect such qualities in the inanimate dead. Instead, it rivets attention on the bodies' physical shape and contour, which are the only relevant concerns of the survivors, who have "trenches" and a mass grave to dig. Rapt in the immediacy of his vision, the speaker does not try falsely to ennoble his feelings with "poetic" vocabulary, but rather presents his feelings in the most accurate and unequivocal way.

What has all this to do with the stanza? So far we have spoken only of "mazes" and of the effort that the poem requires us to expend in unraveling its syntactic inversions and lexical leaps, and in reading its 
astonishing juxtapositions, such as that of a "sweetly" shining moon and "heaps" (in the same line!). But these revelations spin themselves out in the context of carefully crafted stanzas. To speak of the poem, as I have, as if it were an automatic transcription of the speaker's dreams is, of course, an exaggeration. What we read is not an automatically recorded jumble of images, or the spontaneous visionary rhetoric of a "Kubla Khan." Even as he relates his confusions the speaker is ordering them. Not that he has achieved a consummate order, but he has made a start. Thus each section of the poem is four lines long; each begins with a relatively short line that is followed by a longer line and another shorter line. Even the syntax that unbalances us in stanza one turns out, on closer look, to be ordered in the familiar and neat Whitmanian parallelism. Parallel prepositional phrases - "of . . . of . . . ," etc. lead us (and the speaker) through the bewildering syntactic inversions and the various minor embeddings that obstruct our passage through the poem. Parallelism cuts a path of sense, of meaning, which - if not definitive-is at least a start.

The stanzaic form embodies the ordering process itself: the mind's effort to wrestle shape from the most baffling experience. The refrain, which is the most obvious pattern of verbal repetition across stanzas, underscores not only the stubborn persistence of the dreams, but the speaker's tenacious resolve to make sense of them. It is characteristic of this very short but complex poem that the refrain should both suggest the relentless inscrutability of the dreams and the will to order them.

Clearly, though he has often been hailed as the parent of American free verse, Whitman could no more expunge traditional forms and rhythms from his poetry than he could extricate himself from his times. His most masterful uses of tradition, however, transcend mere mimicry of old forms to articulate, expressively, the most subtle psychological moods and modulations. These modulations are not on the grand scale of those in "Cradle" or "Lilacs" but of the more minutely intimate character that distinguishes the later poetry, in which Whitman-with diminished breadth but undiminished depth of insight-confronts the complexities of advancing age and his war-haunted memory. In these poems traditional and nontraditional elements fuse. They evoke in us something of the elusiveness and the music-even the operatic drama-that Whitman continually promises us in his poems, and in his companionship, along the open road.

Weber State College 


\section{NOTES}

1 Herbert Bergman, "Whitman on His Poetry and Some Poets: Two Uncollected Interviews," American Notes and Queries 8 (February 1950), 164.

2 Killis Campbell and Roger Asselineau have compared the traditional poems to Whitman's non-traditional poems, especially those of $1855-1856$, and have indicated that his later poems and poem revisions are more "metrical" and conventional. See Campbell, "The Evolution of Whitman as Artist," American Literature 6 (1934), 254-263; Asselineau, "Prosody," in The Evolution of Walt Whitman: The Creation of a Book (Cambridge: Harvard University Press, 1962), 239-252. Though their view of Whitman's conventionalism is by no means entirely negative-both, in fact, assert that Whitman's use of more traditional technique shows a heightened musicality (Campbell, 257, 259; Asselineau, 248) - they seem to imply the inferiority of these poems by only mentioning them in passing.

While a few critics have attempted traditional scansions of some Whitman poems, others have steadfastly rejected any application of traditional prosodic analysis to Whitman's work. Pasquale Jannacone (1897) believed Whitman's prosody was grounded in parallelism and the strophe, yet he applied conventional methods of scansion to two subclasses of Whitman's poems, which he termed "poems in definite rhythm and rime" and "poems of clear rhythmic design." See his Walt Whitman's Poetry and the Evolution of Rhythmic Forms and Walt Whitman's Thought and Art, trans. Peter Mitilineos (Washington: NCR Microcard Editions, 1973), 20.

In the opposite camp is Gertrude $M$. White, who criticized Jannacone's work when it appeared in English translation in 1973 for applying conventional scansion to Whitman's unconventional work. (See her review of Walt Whitman's Poetry and the Evolution of Rhythmic Forms and Walt Whitman's Thought and Art, in the Walt Whitman Review 19 [Sept. 1973], 121). In Sound and Form in Modern Poetry (Ann Arbor: University of Michigan Press, 1964) Harvey Gross contends that Whitman substituted syntax for meter as his great prosodic principle and that, consequently, traditional scansion "has no relevance to Whitman's prosody" (84-85). Gross, however, does not address such poems as "Pioneers! O Pioneers!," "O Captain! My Captain!," "Ethiopia Saluting the Colors," and others which have a clear metrical base.

Other scholars-such as Jannacone, Campbell, and Gay Wilson Allen-have identified numerous Whitman poems using stanzas and/or traditional meters. Jannacone classes three Whitman poems as having "definite rhythm and rime"-i.e., they use one of the stanzaic forms "recognized and governed by English metrics" (20): the song portions and refrain of "The Singer in the Prison"; "Ethiopia Saluting the Colors"; and "O Captain! My Captain!" He also categorizes a larger number of poems as "poems of clear rhythmic design" (i.e., unrhymed poems in which lines within a group or "strophe" are of varying lengths, though the strophes themselves are of uniform length [30]). These include "Pioneers! O Pioneers!," which has a four-line stanza and trochaic rhythm; "Old War-Dreams," also in a four-line stanza; "Eidolons"; "Dirge for Two Veterans"; "Darest Thou Now O Soul"; "Beat! Beat! Drums!"; “Gods," in which strophes vary in size, though a refrain is kept; and "For You O Democracy" (30-49).

Campbell identifies several poems as having "an iambic movement": "Prayer of Columbus," "The Mystic Trumpeter," "Joy, Shipmate, Joy," "Song of the Universal," "To the Man-of-War Bird," "Thou Orb Aloft Full Dazzling," "A Riddle Song," and four others, and many poems in the annexes "Sands at Seventy," "Good-Bye My Fancy," and "Old Age Echoes" (261-262).

Allen says that, although Whitman's form was organic, his emotion and thought sometimes found "natural expression in rime and meter" (The New Walt Whitman Handbook [New York: New York University Press, 1975], 239). As examples he names 
the opening of "Song of the Broad-Axe," section one of "By Blue Ontario's Shore," "O Captain! My Captain!," "The Singer in the Prison," and "Ethiopia Saluting the Colors." Among poems using stanza forms he identifies "A Noiseless Patient Spider" and several poems mentioned by Jannacone (e.g., "Pioneers! O Pioneers!," "Dirge for Two Veterans," and "Beat! Beat! Drums!") (240-241).

3 Thomas L. Brasher, who collected and edited 21 of these poems in The Early Poems and the Fiction (New York: New York University Press, 1963), judiciously writes that these pieces "are didactic in the fashion of the American school of graveyard poetry as established by Bryant and sentimental in the manner of Shelleyan self-pity and Keatsian frustration. Neither this sort of didacticism nor this sort of sentimentalism is characteristic of the later Leaves of Grass" (xv).

4 Leaves of Grass, Comprehensive Reader's Edition, ed. Harold W. Blodgett and Sculley Bradley (New York: New York University Press, 1965), 337-338. Hereafter LG.

5 Walt Whitman Reconsidered (New York: William Sloane Associates, 1955), 134.

6 Gay Wilson Allen, The New Walt Whitman Handbook (New York: New York University Press, 1975), 240.

7 Vaughan Hudson, “Melville's Battle-Pieces and Whitman's Drum-Taps: A Comparison," Walt Whitman Review 19 (Sept. 1973), 91.

8 J. R. Lemaster, "Some Traditional Poems from Leaves of Grass," Walt Whitman Review 13 (1967), 49.

9 "The Delicacy of Walt Whitman," in Walt Whitman, The Measure of His Song, ed. Jim Perlman, Ed Folsom, and Dan Campion (Minneapolis: Holy Cow! Press, 1981), 163-164.

10 F. DeWolfe Miller, ed., Walt Whitman's Drum-Taps (1865) and Sequel to Drum-Taps (1865-6): A Facsimile Reproduction (Gainesville, Florida: Scholars' Facsimiles and Reprints, 1959), ix.

$11 L G, 570$.

12 M. Wynn Thomas, "The Pains and Obligations of Memory," in The Lunar Light of Whitman's Poetry (Cambridge: Harvard University Press, 1987), 205-251. 